\title{
An unusual etiology in cold injury: Liquefied petroleum gas
}

\author{
Emin Kapı, M.D., ${ }^{1}$ Mehmet Bozkurt, M.D., ${ }^{2}$ Gaye Taylan Filinte, M.D., ${ }^{2}$ \\ Samet Vasfi Kuvat, M.D., ${ }^{3}$ Celal Alioğlu, M.D. ${ }^{2}$
}

\begin{abstract}
${ }^{1}$ Department of Plastic, Reconstructive and Aesthetic Surgery, Adana State Hospital, Adana-Turkey
${ }^{2}$ Department of Plastic, Reconstructive and Aesthetic Surgery, Kartal Dr. Lütfi Kırdar Training and Research Hospital, İstanbul-Turkey

${ }^{3}$ Department of Plastic, Reconstructive and Aesthetic Surgery, İstanbul University İstanbul Medical Faculty, İstanbul-Turkey
\end{abstract}

\begin{abstract}
Cold injury is a condition that causes reversible and irreversible damage when tissues are exposed to cold. This injury occurs due to various etiologies, and the most commonly observed ones include contact with liquefied petroleum gas (LPG) used in households, vehicles, and industry. LPG is a type of gas stored in liquid state under high pressure within cylinders. LPG contains a mixture of propane and butane gases. Direct contact of these gases with the tissues has the potential to cause metabolic, toxic, and respiratory damage. In this study, we present the cases of four patients with cold injury in the face and upper extremity caused by a pressurized jet stream of liquid gas that escaped out of the valves of the LPG cylinders. The patients had bullous lesions in the upper extremities and the face and second- and third-degree cold injuries with fibrotic and necrotic areas. The superficial defects secondarily healed with minimal scarring, while the necrotic finger had to be amputated. Cold injury on the skin caused by high-pressure jet streams of liquid gas as in our study is a rare occurrence. Our patients are important cases due to the rare etiology of cold injury.
\end{abstract}

Keywords: Amputation; cold injury; LPG.

\section{INTRODUCTION}

Liquefied petroleum gas (LPG) is a substance obtained by condensing flammable liquid petroleum gas at high pressure, and every gas cylinder contains a mixture of cold liquid and gaseous forms. ${ }^{[1]}$ Although the pressurized substance is in a liquid state, it transforms into a gaseous form under normal atmospheric pressure. ${ }^{[2]}$ The gas is extensively used in the household and industry. ${ }^{[1,3]}$ While it has been used for domestic heating purposes for a long time, it is also widely used as a vehicle fuel and a commercial fuel. ${ }^{[1,2,4,5]}$ The number of vehicles equipped with LPG cylinders is estimated to be more than 8 million worldwide. Due to its lower cost and environmentally friendlier nature in comparison to other pe-

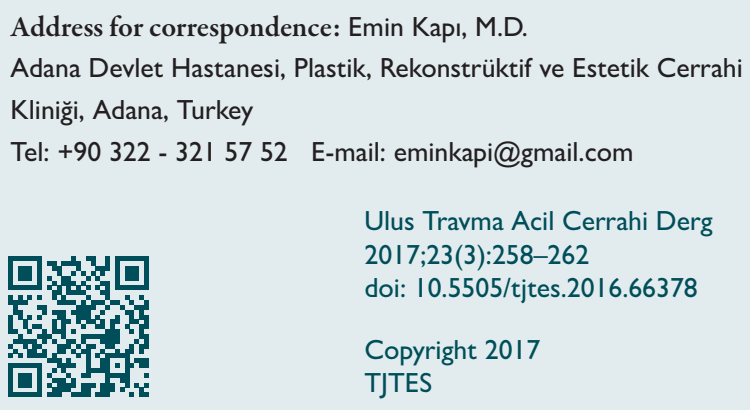

troleum products, LPG has been becoming more popular in recent years. ${ }^{[6,7]}$ LPG contains $60 \%$ butane and $40 \%$ propane. [2] These gases are colorless, odorless, and heavier than air. Although the boiling point of propane and butane varies according to the hydrocarbon content, it is between $-42^{\circ} \mathrm{C}$ and $6^{\circ} \mathrm{C} \cdot{ }^{[2,8]}$ The tissue-damaging potential of volatile liquid propane gas is well known. ${ }^{[9]}$

When LPG stored at a low boiling point and high pressure within the cylinder comes in direct contact with the skin at room temperature, a type of frostbite injury known as cold injury occurs. ${ }^{[1,10]}$ This type of trauma is rarely observed. ${ }^{[2,9]}$ Contact with the eyes can also lead to irritations. ${ }^{[1]}$ Contact with LPG usually occurs due to leakages from the LPG cylinder or from the gas that squirts when the cover is opened during refueling of the vehicle. $\left.{ }^{[8,1}\right]$ The morbidity of the tissue damage depends on the severity of the damage and the extent of the affected tissue. ${ }^{[8,12-15]}$ In this study, we present the clinical progression of four patients with tissue damage on the face and upper extremities due to direct contact with LPG and the measures to be taken to prevent such damage.

\section{MATERIALS AND METHODS}

Four male patients presented to our clinic with cold injury on the face and upper extremities due to direct contact with 
LPG. The mean age of the patients was 32.4 years (range: 26-44 years). Two of them were injured when they were replacing the LPG cylinder at home; one patient was exposed to gas when he was trying to close the cover of the LPG tank in the vehicle, and the other patient was injured when he came in direct contact with the gas leaking through the valve of the LPG tank during refueling at the gas station. These patients reportedly attempted to apply pressure on the valve of the LPG cylinder with their hands to stop the leakage but could not prevent the contact of the jet stream of the gas with the upper extremities and the face, which led to the tissue damage. They stated that they felt pain and coldness in the affected area immediately after the injury, which subsided after a few hours. Two patients did not even seek medical help after the injury.

The first patient presented to the emergency room due to increasing pain in the volar and dorsal surfaces of the first to third fingers of the right hand and the loss of sensation and formation of bullae and vesicles in these fingers on the $2^{\text {nd }}$ day following the injury that was caused when he was replacing the LPG cylinder at home. In the emergency room, incisions were made on the bullae and blisters. He presented to our clinic on the $3^{\text {rd }}$ day. His physical examination revealed a circular edema at the metacarpal level, bullae, and vesicles in the right hand, and widespread epidermolysis and macerations in all the fingers (Figure I). Examination of blood circulation demonstrated that the distal circulation in the second and third phalanges was disturbed up to the level of the proximal

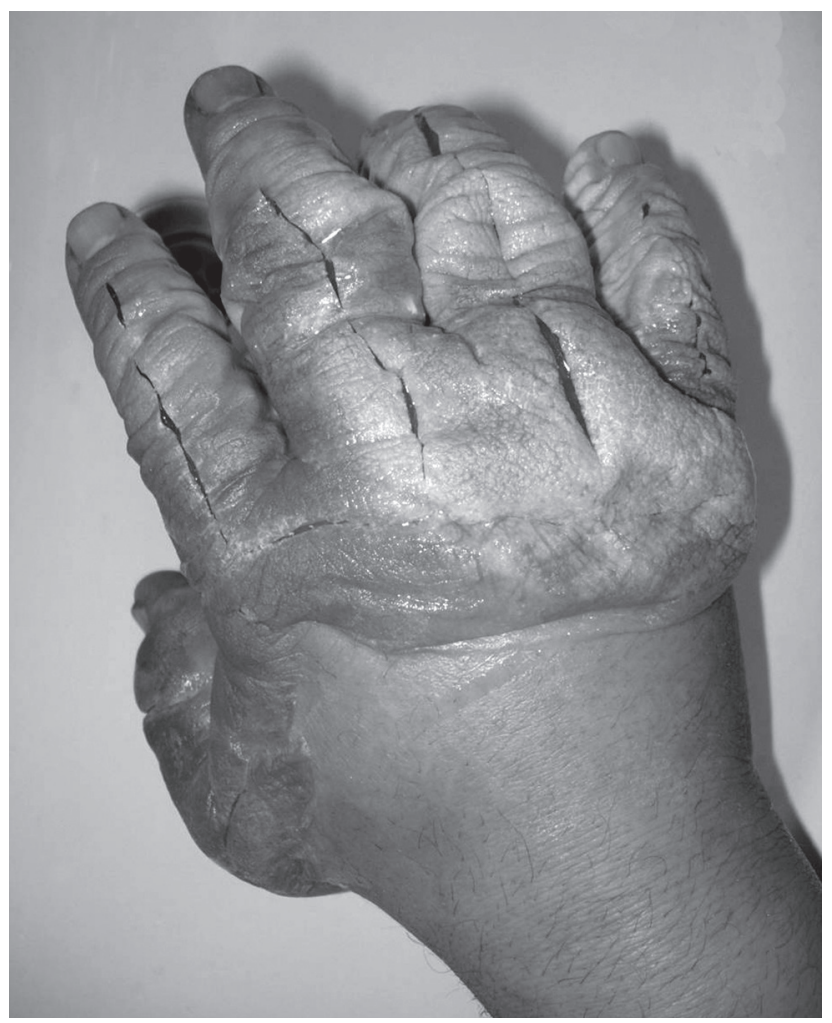

Figure 1. View of the patient with vesicles and macerations due to cold injury in the right hand. phalanges, while the circulation was weakened especially in the dorsal region.

The second patient reported that the cold injury in his right forearm and hand had occurred due to exposure to a spray of liquid gas for about $20 \mathrm{~s}$ when he was trying to tighten the cover of the LPG tank in his vehicle to prevent the gas leakage. $\mathrm{He}$ had a skin defect with vesicular--bullous lesions at the level of the elbow progressing distally primarily at the distal side of the right upper extremity (Figure 2). There was a mild sensory loss in the fingers due to the edema. The other patients also had superficial erythematous, bullous, and fibrous defects and blisters on the upper extremities and the face (Figure 3). These defects were painful accompanied by leakage of fluid.

When the patients were questioned about LPG and its effects, it was understood that they did not have any knowledge on the possibility of developing a cold injury due to contact with LPG.

The defects received thermal damage treatment. Under local anesthesia, the defects were debrided and the bullae and vesicles were excised. All the patients were started on a regimen of nonsteroidal anti-inflammatory drugs and wide-spectrum antibiotics, while the patient with circulation disturbances in the fingers was also prescribed low-molecular dextran and acetylsalicylic acid. The extremities with defects were elevated. The wounds were dressed daily with paraffin and moisturizing dressing materials.

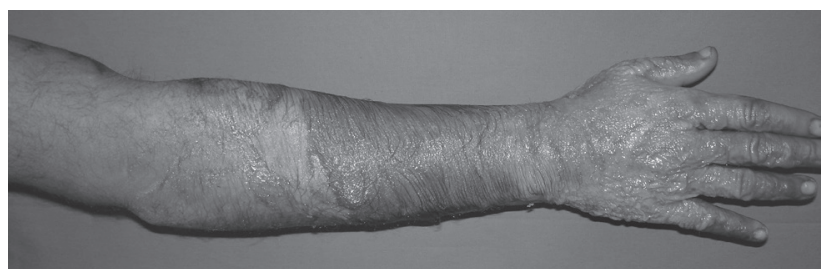

Figure 2. View of the patient with skin macerations due to contact with LPG in the right forearm and hand.

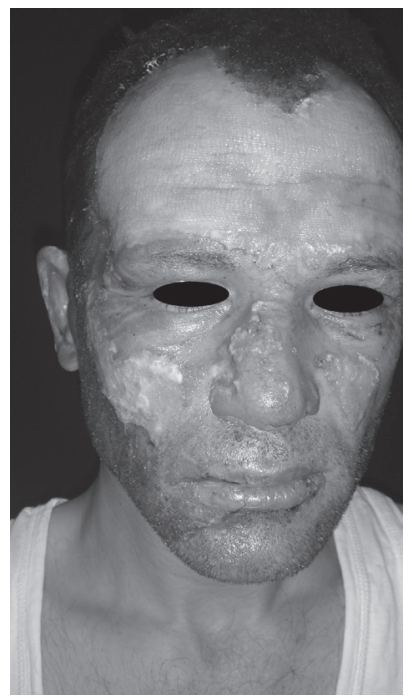

Figure 3. View of the erythematous and epidermolytic areas due to contact with liquid gas in the facial area. 


\section{RESULTS}

The first patient did not seek medical help because of not feeling the pain on the Ist day of exposure to the trauma; however, on the $2^{\text {nd }}$ day, due to the obvious pain and edema, he visited the emergency department. On the $2^{\text {nd }}$ day, as he was sent home from the emergency department after opening the blisters, it caused a delay in adequate and appropriate intervention. The epidermolytic areas on the first to fourth metacarpals and the volar thenar regions of the volar and dorsal surfaces of the hand healed secondarily. The superficial defects in the fifth phalanx and the bullous lesions on the anterior surface of the first phalanx also healed secondarily. On the $7^{\text {th }}$ day after his visit, the demarcation lines in the second to fourth phalanges started becoming visible (Figure 4a). The necrotic areas in a circular manner in the second and third phalanges and the proximal dorsal region of the fourth phalanx became apparent. Under general anesthesia, amputations were performed at the level of the proximal phalanx in the second and third phalanges and at the level of the medial phalanx in the fourth phalanx, and the defects were repaired. The necrotic tissues in the other phalanges were debrided. The patient was discharged on the $2^{\text {nd }}$ postoperative day. No wound healing problems were observed in the early phase after the surgery, and all the defects healed completely in the $2^{\text {nd }}$ postoperative month (Figure $4 b$ ).

The second patient did not seek medical help assuming that his wounds were mild.

In the other patients, the defects healed completely within approximately 3 weeks after the injury leaving sporadic areas
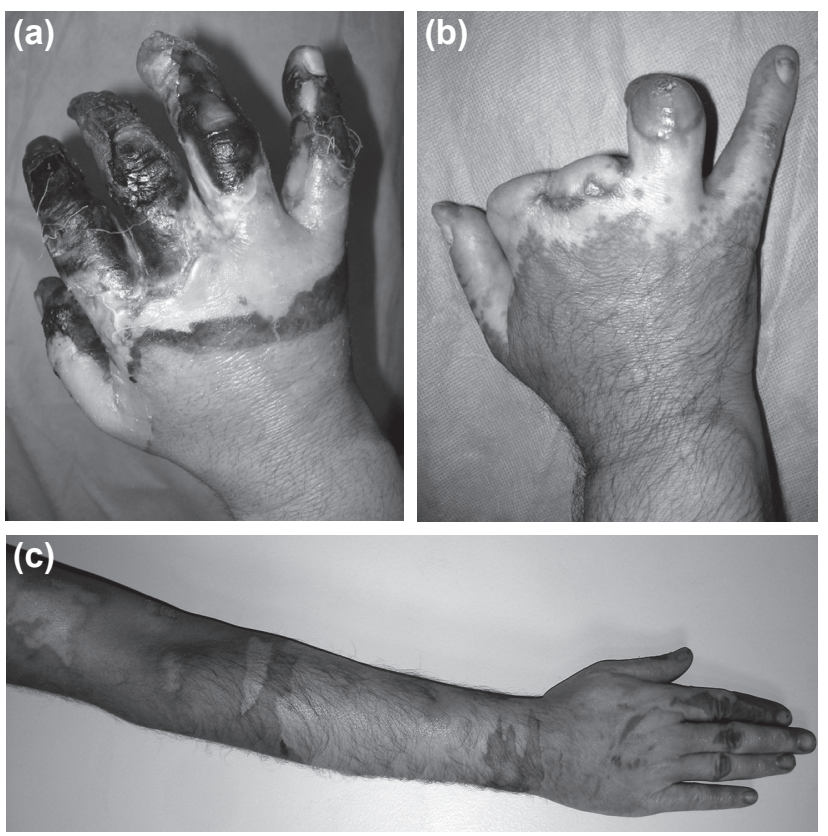

Figure 4. (a) The patient with full-thickness necrosis in the phalanges. (b) The patient at the $2^{\text {nd }}$ postoperative month following the phalangeal amputation. (c) The patient with secondary healing in the upper extremity defect 3 weeks after the injury. of hyperpigmentation. The functions of the extremities were normal (Figure 4c). These patients were started on a hand physiotherapy program.

\section{DISCUSSION}

LPG is a commonly used fuel worldwide. In recent years, it has become increasingly more commonly used in households, offices, camping places, vehicles, and industry. ${ }^{[9]}$ This fuel is extremely flammable and may therefore cause serious flame burns. ${ }^{[12]}$ On the other hand, due to its chemical characteristics, LPG may also cause cold injuries when it comes into direct contact with the skin. Although burn injuries due to LPG are commonly reported worldwide, the literature reports on cold injuries due to direct contact are limited in number. ${ }^{[9]}$ In this context, the patients described in our study are very interesting. No studies investigating the correlation between gender and LPG-related cold injury have been found in the literature. However, a predominance of male gender among patients has been observed. Similarly, all the patients in our study were males, which is related to the fact that occupations on LPG tanks are frequently done by men. Therefore, males can be considered to be at an increased risk compared with females.

Cold injuries may present with several clinical findings according to the degree of the cold and the length of exposure. ${ }^{\left[{ }^{[1]}\right]}$ The injury may involve a partial- or full-thickness cutaneous damage of unknown depth. ${ }^{[16-18]}$ Nevertheless, deep injuries are more frequently observed. ${ }^{[16]}$ The damage on the skin is usually in the form of epidermolysis, bullae, and vesicles as in flame burns. Tissue necroses may also occur depending on the damage in the deeper tissues. ${ }^{[17-19]}$ The clinical spectrum ranging from superficial defects to necrosis and amputations indicates that the findings are highly variable. The exposure time of the liquid gas is quite a determining factor in the variety of clinical findings. Hicks et al. have demonstrated in their animal studies that direct exposure of the skin to propane for $12 \mathrm{~s}$ leads to epidermal necrosis, whereas an exposure for 30 $\mathrm{s}$ causes dermal necrosis at the end of $24 \mathrm{~h}$ and damage in the superficial muscles after 5 days. ${ }^{[17]}$ In our study also, the exposure time in patients with necrosis was about 15-20 s. Short-term liquid gas exposure in our patients was similar to experimental results.

The intense damage despite the short exposure time of LPG is related to the skin contact of the cold liquid gas, which is compressed under high pressure in the tank and leaks out with a high acceleration from the tank lid. This damage occurs due to the loss of heat from the skin and the underlying tissues within a few seconds as the LPG is transformed from the liquid form into the volatile gas form without combustion. $[1,9,17]$ This rapid transformation shows its effect quickly and causes tissue damage in a short period of time extending into the deep tissue. Therefore, a cold injury could be more severe than other injuries caused due to flame burns. However, 
comparative clinical trials should be done on this issue.

Although the cold injury appears to be superficial during the first few days after the exposure, it may cause greater damage than initially expected. ${ }^{[20,21]}$ Therefore, an evaluation of the tissues based on the appearance of the uppermost layers may not be reliable in the early period. ${ }^{[22]}$ Indeed, in one of the patients in our study, the apparently mild skin damage immediately after the exposure to LPG led the healthcare providers to assess the damage as superficial. After the discharge, the patient did not seek further treatment as his pain diminished. When his clinical status deteriorated in the subsequent period, he returned to the emergency room to continue his treatment, but this misdiagnosis delayed healing. Therefore, in cold injuries caused due to LPG, degenerative tissue necroses that may develop in later phases should not be overlooked. It should also be considered that the findings may become clearer in later phases, and the patients should be kept under close monitoring from the first day onward.

In case of a cold injury, the recommended first aid methods are washing the skin area that came into contact with the liquid gas with soap and water and warming up the skin in water close to the body temperature. ${ }^{[2,23-25]}$ Wrapping the injured area immediately with a warm compress may help to warm up the area gradually. After the warm-up, the area with bullae, vesicles, and epidermolysis should be debrided. In patients at risk of compartment syndrome, an escharotomy and fasciotomy should be performed on the injured extremity, followed by sterile application of topical antibacterial agents chosen according to the nature of the defect. ${ }^{[2,26]}$ Prophylactic treatment against infection and thrombosis, systemic antibiotherapy, anti-inflammatory agents, elevation of the extremity, hyperbaric oxygen therapy (HBO), and treatment with circulation-enhancing agents (dextran 40-500 ml/24 h, lowmolecular-weight heparin $6.000 \mathrm{IU} / 0.6 \mathrm{ml}$, acetylsalicylic acid $80-100 \mathrm{mg} / 24 \mathrm{~h}$, vasodilatatory agent, and pentoxifylline) are among the methods for preventing deterioration of the tissue damage. Distal circulation should be monitored by pulse oximetry. ${ }^{[27]}$

The most effective strategy for avoiding cold injury due to LPG exposure is prevention. Individuals should be warned against the danger of direct contact. Care must be taken during replacement of the LPG cylinders in households or offices, and professional assistance should be sought when necessary. The valves of the tanks should be regularly checked. Especially the tank nozzles and pumps in gas stations should be regularly checked and closely monitored. Vehicle users and gas station employees should be aware of the risks of liquid gas exposure during refueling. We believe that this issue should be emphasized during the in-service training of the fuel station staff.

Although the necessary measures against the risk of explosion of LPG tanks and cylinders are well known among the general population, there is only inadequate awareness regarding the risk of cold injuries due to direct contact with LPG among both the general population and healthcare professionals in emergency rooms. ${ }^{[19]}$ Therefore, the first aid measures to be taken in case of such injuries are usually neglected, although they are simple and easy to apply. Although rare, since this type of injury has the potential to cause functional losses in the extremities and permanent malformations on the face, it may have an impact on the social life of the patient. It has been observed that the subject does not draw adequate attention in the mass media, and not enough public education is given. ${ }^{\text {[9] }}$ Since none of our patients had information regarding cold injury, it is clear that this issue needs adequate attention. Furthermore, we believe that healthcare workers should be trained especially on first aid attempts, and regarding the society, the work of the public spotlight should be expanded.

\section{Conclusion}

Direct contact with the gases present in LPG may cause varying degrees of cold injuries and tissue necroses, especially in the extremities. The greatest problem associated with this type of trauma is the limited clinical experience of healthcare professionals on the diagnosis and treatment, the tissue damage that manifests itself in later phases after the injury, and the delayed medical care due to the late referral of the patient to the healthcare facility. Therefore, to reduce morbidity in cold injuries caused due to LPG or similar etiologies, it is important that the patients refer a medical facility at an early stage and the healthcare providers be aware of the grading of cold injuries.

\section{Conflict of interest: None declared.}

\section{REFERENCES}

1. Bonamonte D, Profeta G, Conserva A, Mazzoccoli S, Foti C, Angelini G. Cold burn from contact with a propane and butane gas blend inside a spray canister used as a hooter. Contact Dermatitis 2008;59:61-2. [CrossRef]

2. Wright TC, Kim JB, Currie LJ, Kay AR, Burge TS. Leakage of liquefied petroleum gas during motor vehicle refuelling--a new cause of cold injury. Burns 2006;32:132-3. [CrossRef]

3. Stawczyk J. Experimental evaluation of LPG tank explosion hazards. J Hazard Mater 2003;96:189-200. [CrossRef]

4. Murugkar PM, Jones NW, Shokrollahi K, Potokar TS, Drew PJ, Dickson WA. Hand burns sustained whilst refuelling car with LPG (liquefied petroleum gas). Burns 2006;32:515-6. [CrossRef]

5. Paliwal G, Agrawal K, Srivastava RK, Sharma S. Domestic liquefied petroleum gas: are we using a kitchen bomb? Burns 2014;40:1219-24.

6. Kumar P. Fire disaster following LPG tanker explosion at Chala in Kannur (Kerala, India): August 27, 2012. Burns 2013;39:1479-87. [CrossRef]

7. Zengin Y, Dursun R, İçer M, Gündüz E, Durgun HM, Erbatur S, et al. Fire disaster caused by LPG tanker explosion at Lice in Diyarbakır (Turkey): July 21, 2014. Burns 2015;41:1347-52. [CrossRef]

8. Scarr B, Mitra B, Maini A, Cleland H. Liquefied petroleum gas cold burn sustained while refueling a car. Emerg Med Australas 2010;22:82-4.

9. James NK, Moss AL. Cold injury from liquid propane. BMJ 1989;299:950-1. [CrossRef]

10. Tarim MA. Evaluation of burn injuries related to liquefied petroleum gas. 
J Burn Care Res 2014;35:159-63. [CrossRef]

11. Woo EK, Lee JW, Hur GY, Koh JH, Seo DK, Choi JK, et al. Proposed treatment protocol for frostbite: a retrospective analysis of 17 cases based on a 3-year single-institution experience. Arch Plast Surg 2013;40:5106. [CrossRef]

12. Bozkurt M, Kulahci Y, Zor F, Kapi E. Burn injuries related to liquefied petroleum gas-powered cars. J Burn Care Res 2008;29:897-901. [CrossRef]

13. Nowakowski A, Kaczmarek M, Renkielska A, Grudzinski J, Stojek W. Reaction of normal and burned tissue to cold excitation. Conf Proc IEEE Eng Med Biol Soc 2007;2007:239-42. [CrossRef]

14. Carpenter HM, Hurley LA, Hardenbergh E, Williams RB. Vascular injury due to cold. Affects of rapid rewarming. Arch Pathol 1971;92:15361.

15. Geng Z, Tong X, Jia H. Reactive oxygen species (ROS) mediates nonfreezing cold injury of rat sciatic nerve. Int J Clin Exp Med 2015;8:157007.

16. Corn CC, Wachtel TL, Malone JM, Wood M. Liquid-propane freeze injury: a case history. J Burn Care Rehabil 1991;12:136-9. [CrossRef]

17. Hicks LM, Hunt JL, Baxter CR. Liquid propane cold injury: a clinicopathologic and experimental study. J Trauma 1979;19:701-3. [CrossRef]

18. Li AK, Ehrlich HP, Trelstad RL, Koroly MJ, Schattenkerk ME, Malt RA. Differences in healing of skin wounds caused by burn and freeze injuries. Ann Surg 1980;191:244-8. [CrossRef]

19. Seyhan N, Jasharllari L, Kayapınar M, Savacı N. An unusual cause of cold injury: liquified petroleum gas leakage. Ulus Travma Acil Cerrahi Derg 2011;17:561-2. [CrossRef]

20. Mäkinen TM, Jokelainen J, Näyhä S, Laatikainen T, Jousilahti P, Hassi J. Occurrence of frostbite in the general population--work-related and individual factors. Scand J Work Environ Health 2009;35:384,93.

21. Mehrkens HH. Cold injuries and thermal lesions. [Article in German] ZFA (Stuttgart) 1981;57:209-21. [Abstract]

22. Fudge JR, Bennett BL, Simanis JP, Roberts WO. Medical Evaluation for Exposure Extremes: Cold. Clin J Sport Med 2015;25:432-6. [CrossRef]

23. Uygur F, Sever C, Noyan N. Frostbite burns caused by liquid oxygen. J Burn Care Res 2009;30:358-61. [CrossRef]

24. Sachs C, Lehnhardt M, Daigeler A, Goertz O. The Triaging and Treatment of Cold-Induced Injuries. Dtsch Arztebl Int 2015;112:741-7.

25. Nygaard RM, Whitley AB, Fey RM, Wagner AL. The Hennepin Score: Quantification of Frostbite Management Efficacy. J Burn Care Res 2016;37:317-22. [CrossRef]

26. O'Brien C, Castellani JW, Muza SR. Acute Hypobaric Hypoxia Effects on Finger Temperature During and After Local Cold Exposure. High Alt Med Biol 2015;16:244-50. [CrossRef]

27. Keramidas ME, Kounalakis SN, Eiken O, Mekjavic IB. Effects of Two Short-Term, Intermittent Hypoxic Training Protocols on the Finger Temperature Response to Local Cold Stress. High Alt Med Biol 2015;16:251-60. [CrossRef]

\section{OLGU SERISİ - ÖZET}

\section{Donuk hasarında alışılmadık bir etiyoloji: Likit petrol gaz \\ Dr. Emin Kapı, ${ }^{1}$ Dr. Mehmet Bozkurt, ${ }^{2}$ Dr. Gaye Taylan Filinte, ${ }^{2}$ Dr. Samet Vasfi Kuvat, ${ }^{3}$ Dr. Celal Alioğlu ${ }^{2}$}

${ }^{1}$ Adana Devlet Hastanesi, Plastik, Rekonstrüktif ve Estetik Cerrahi Kliniği, Adana

${ }^{2}$ Kartal Dr. Lütfi Kırdar Eğitim ve Araştırma Hastanesi, Plastik, Rekonstrüktif ve Estetik Cerrahi Kliniği, İstanbul

${ }_{3}^{3}$ Istanbul Üniversitsi İstanbul Tıp Fakültesi, Plastik, Rekonstrüktif ve Estetik Cerrahi Anabilim Dalı, İstanbul

Donuk hasarı, soğuğa doğrudan ya da dolaylı yoldan maruz kalınması sonucunda etkilenen dokuda geri dönüşümlü ya da dönüşümsüz harabiyete neden olan bir durumdur. Donuk hasarı oluşumuna yol açan farklı etiyolojik nedenler bulunmaktadır. Bunlar arasında en sık karşış̧ılan nedenler; ev, araç ya da endüstriyel alanlarda kullanılan LPG (liquefied-petroleum gases) temasına bağı hasarlardır. LPG, yüksek basınç altında tanklar içerisinde sıvı halde depolanan bir yakıt türüdür. Iç̧eriğinde propan ve bütan gazları karışım halinde bulunur. Bu gazların, dokularla direkt temas halinde metabolik, toksik ve solunumsal hasar oluşturma potansiyeli bulunmaktadır. Bu çalışmada, LPG tankının kapakçıklarından likid formdaki gazın yükssek basınçla fışkırması sonucunda oluşan jet akıma bağlı olarak üst ekstremite ve yüzde donuk hasarı oluşmasına neden olan dört olgu değerlendirildi. Olgularda üst ekstremite ve yüzde büllöz lezyonlar, fibrotik ve nekrotik alanlar içeren ikinci ve üçüncü derece donuk hasarları mevcuttu. Yüzeyel defektler sekonder olarak yer yer minimal skar alanları bırakarak iyileşti, parmaklarda nekroz gelişen olguya amputasyon uygulandı. Çalışmamızdaki olgularda olduğu gibi, likit nitrojen içeriğinin yüksek basınçla fışkırması ve deride donuk hasarı oluşturması sık rastlanan bir durum değildir. Olgularımız farklı bir donuk etiyolojisine sahip olması nedeniyle oldukça ilgi çekicidir.

Anahtar sözcükler: Amputasyon; LPG; soğuk hasarı.

Ulus Travma Acil Cerrahi Derg 2017;23(3):258-262 doi: 10.5505/tjtes.2016.66378 